\title{
MODELOVÁNÍ INDENTACE DO TVRDÝCH A KŘEHKÝCH MATERIÁLŮ
}

\section{MODELING OF THE INDENTATION INTO HARD AND BRITTLE MATERIALS}

\author{
Dušan Zíta 1,*, Petr Hanus ${ }^{2}$
}

\begin{abstract}
Abstrakt
Tento článek se zabývá stručným popisem modelování indentace do tvrdých a křehkých materiálü, např́íklad skla, vrstveného skla nebo různých druhů keramiky pomocí metody konečných prvků. Vytvořený model je velmi užitečný jako podpora indentační zkoušky proto, že touto cestou získáme další materiálové charakteristiky, které je obtižné nebo dokonce nemožné získat experimentálně, ale také z důvodu odhalení zdrojů nepřesností měření. Dalším přínosem je možnost zkoumat odezvu nějaké neznámé kombinace vrstvených materiálů a posoudit tak vhodnost použití pro daný účel, aniž by bylo nutné vzorek předem vyrobit.
\end{abstract}

Klíčová slova Instrumentovaná indentace, křehký lom, MKP.

Summary This paper deals with a brief description of indentation modeling into hard and brittle materials, such as glass, laminated glass or various types of ceramics using the finite element method. The created model is very useful as a support for the indentation test because in this way we obtain other material characteristics that are difficult or even impossible to obtain experimentally, but also due to the detection of sources of measurement inaccuracies. Another benefit is the ability to investigate the response of an unknown combination of laminates and assess the suitability for use for a given purpose without the need to pre-fabricate the sample.

Keywords Instrumented indentation, brittle fracture, FEM.

\section{1 ÚVOD}

Pro různé obory lidské činnosti, jako je strojírenství, doprava či stavitelství, je důležitá znalost mechanických vlastností používaných materiálů. Ty jsou $\mathrm{v}$ různých aplikacích např. $\mathrm{v}$ dopravních prostředcích, vystaveny rozmanitým zátěžovým stavům (vibrace vyvolané jízdou po nerovné vozovce nebo chod motoru, náhlé změny rychlosti, srážky s cizími objekty). Tyto zátěžové stavy je možné díky rostou cím výkonům výpočetní techniky zahrnout do výpočtového modelu a ověřit či předpovědět chování jednotlivých materiálů $\mathrm{v}$ reálných podmínkách. Čím přesnější informace o materiálu máme, tím

\footnotetext{
${ }^{1}$ Univerzita Pardubice, Dopravní fakulta Jana Pernera, Katedra mechaniky, materiálů a částí strojůn, Studentská 95, 53210 Pardubice, Česká republika

${ }^{2}$ Univerzita Pardubice, Dopravní fakulta Jana Pernera, Katedra dopravních prostředků, Studentská 95, 53210

Pardubice, Česká republika

* korespondenční autor, tel.: +420 466038 928, e-mail: Petr.Hanus@upce.cz
} 
přesnějších výsledků dosáhneme. Zefektivní se tím vývoj daného produktu a poklesnou náklady spojené s testováním a výrobou prototypů.

Jednou z možností, jak určit mechanické vlastnosti materiálů, je indentační zkouška. Principem indentace je vtlačování indentoru do zkoumaného vzorku. Pomocí indentace je možné zkoumat elastickou, pružněplastickou a časově závislou silovou odezvu. Indentaci lze také použít pro měření vlastností heterogenních materiálů a pro měření lomové houževnatosti u křehkých materiálů. Velkou výhodou indentace také je, že nevyžaduje množství speciálně upravených vzorků. Díky uvedeným vlastnostem je indentace univerzální a perspektivní zkouškou, (Lawn a Evans, 1977), (Lawn et al., 1980).

Simulace indentačního procesu pomocí metody konečných prvků rozšiřuje možnosti samotného testu. Usnadňuje pochopení vnitřních mechanismů, které je obtížné studovat pouze experimentálně. Zkoumaný objem je rozdělen na konečný počet elementů. V průběhu zatěžování a odlehčování je možné zkoumat chování každého elementu zvlášt'. Je možné analyzovat napětí a přetvoření. V případě použití speciálních elementů nebo rozšířené metody konečných prvků XFEM (extended finite element method), můžeme simulovat šíření trhliny.

V této práci je stručně popsán vytvořený MKP model. Součástí práce je také popis experimentu a porovnání výsledků MKP simulace s výsledky reálného testu.

\section{POPIS EXPERIMENTU}

Pro ověření platnosti vytvořeného modelu byl proveden následující experiment. Experimentem je míněno měření mechanických vlastností skla pomocí instrumentované indentace. Principem indentace, jak bylo zmíněno v úvodu, je vtlačování indentoru do zkoumaného vzorku. V průběhu vtlačování je zaznamenávána hloubka vtisku jako funkce síly a času (CSN EN ISO 14577-1, 2002). Z velikosti vzniklých trhlin je vypočítána lomová houževnatost.

\subsection{Měřicí řetězec}

Indentační měření bylo provedeno pomocí univerzálního tvrdoměru ZWICK ZHU2.5, který je vidět na obrázku 1.

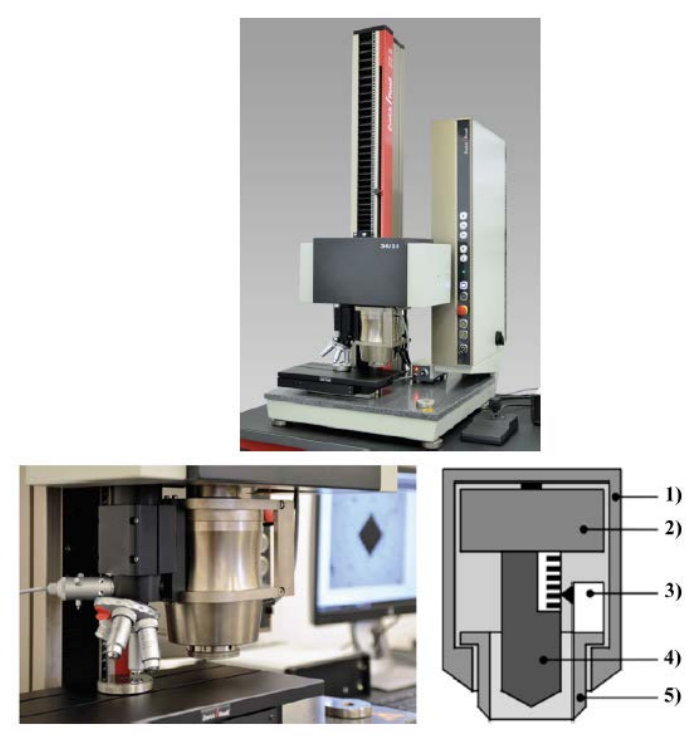

Obr. 1 Měřicí hlava (vlevo), schéma měřicí hlavy (vpravo); (Zíta, 2020)

Hlavní části měřící hlavy nesou čísla na schématickém obrázku 1 vpravo. Jsou to: domeček (1), snímač síly (2), snímač posuvu (3), indentor (4) a takzvaná noha snímače posuvu (5). Standardní rozlišení snímače 
posuvu je $0.002 \mu m$. Noha snímače posuvu je v průběhu měření opřena o kontaktní plochu vzorku. Hloubka vtisku je měřena od kontaktní plochy. Toto opatření minimalizuje vliv poddajnosti rámu měřicího zařízení.

\subsection{Měřené vzorky}

Měřené vzorky skla jsou vyrobeny z automobilového bezpečnostního skla. Vzorek skla má šířku $2 \mathrm{~cm}$ a délku $3 \mathrm{~cm}$. Vzorek skla byl vytvořen odseparováním vrstvy skla z laminovaného skla. K separaci byl použit nůž. Zbytky PVB byly pečlivě očištěny tak, aby vznikl hladký povrch. Je důležité pokládat měřené vzorky přímo na stůl měřicího přístroje. Mezipodložky vnášejí do měření chybu. Při kontaktu dochází k nežádoucí absorpci energie (vymezování vůlí, poddajnost podložky).

\section{MODELOVÁNÍ INDENTACE DO TVRDÝCH A KŘEHKÝCH MATERIÁLŮ}

Tato kapitola představuje model založený na metodě konečných prvků, který je vytvořen tak, aby simuloval indentační měření tvrdých a křehkých materiálů indentorem Vickers. Při vtlačení tohoto geometrického tvaru do zkoumaného materiálu vznikají nejen trvalé deformace, ale také různé druhy trhlin. Simulace indentačního měření zahrnující proces šíření trhlin je poměrně složitý problém.

Proces šíření trhlin je založený na takzvané eliminaci speciálních (kohezivních) elementů. Při splnění určitých kritérí jsou elementy z modelu postupně odebírány. Díky eliminaci ve spojení s materiálovými nelinearitami a s kontaktem je celý výpočtový proces časově velmi náročný. $Z$ tohoto důvodu byl celý problém rozdělen do dvou modelů. Pomocí jednoduchého rotačně symetrického modelu byla provedena kalibrace materiálového modelu. Propojením programovacího jazyka Python, řešiče ABAQUS 6.18 a změřené indentační křivky zkoumaného materiálu byla provedena parametrická studie, jejímž výsledkem byly charakteristiky zkoumaného vzorku.

Nalezené materiálové charakteristiky vstupují do tř́rozměrného modelu. Je zde využito symetrie indentoru Vickers. Modelována je tedy pouze čtvrtina celku. Pomocí tohoto 3D modelu je simulován indentační proces zahrnující šíření trhliny. Podmínky šíření trhliny vycházejí z iniciačního napětí a z energie potřebné pro vytvoření př́ślušné plochy trhliny. Parametry eliminace elementů (iniciační napětí a energie potřebná pro eliminaci elementu) byly nastaveny tak, aby došlo ke shodě změřených a vypočítaných velikostí trhlin. Podrobnější popis jednotlivých modelů lze nalézt v práci (Zíta, 2020).

\subsection{D model šíření trhliny}

\subsubsection{Stručný popis modelu}

Geometrie modelu zobrazená na obrázku 2 obsahuje pouze $1 / 4$ zatěžovaného vzorku. Výška modelu $H=$ $2350 \mu \mathrm{m}$ a poloměr modelu $R=2350 \mu \mathrm{m}$. Model Vickersova indentoru obsahuje také $1 / 4$ celého indentoru. Aby bylo možné ukázat $v$ jakém místě, a ve kterém okamžiku dochází ke vzniku trhlin, byla do modelu zahrnuta oblast kohezivní zóny. Tato zóna má tloušt'ku $0.02 \mu m$.

Sít je vytvořena rotací $2 \mathrm{D}$ sítě podle osy $y$. V radiálním směru je sít rozdělena 15 dělícími rovinami. $V$ okolí koncentrovaného kontaktu vzniknou velmi malé elementy. S rostoucí vzdáleností od osy rotace se radiální velikost elementů zvětšuje. Minimální délka hrany nejmenšího elementu v okolí kontaktu amin $=0.3 \mu m$, maximální délka hrany nejmenšího elementu $a=2.99 \mu m$ (obrázek 38). Indentor je modelován tř́ a čtyřuzlovými 2D elementy o tloušt'ce $t=1 \mu \mathrm{m}$. Vzorek skla je diskretizován 3D lineárními elementy C3D8 a C3D6, kde 3D znamená tři rozměrný prostor, čísla 8 a 6 značí počet uzlů elementu. Při menších rozměrech totiž narážíme na problém s časovou náročností výpočtu.

Indentor je modelován pomocí dokonale tuhých ploch, jež jsou svázány „rigid body“ vazbou do řídícího uzlu, kterému je předepsána podmínka posuvu ve směru „y“. Stejnému posuvu jako při reálném měření. Podrobnější popis okrajových podmínek, popis materiálového modelu a definici kontaktních páru lze nalézt v práci (Zíta, 2020). 


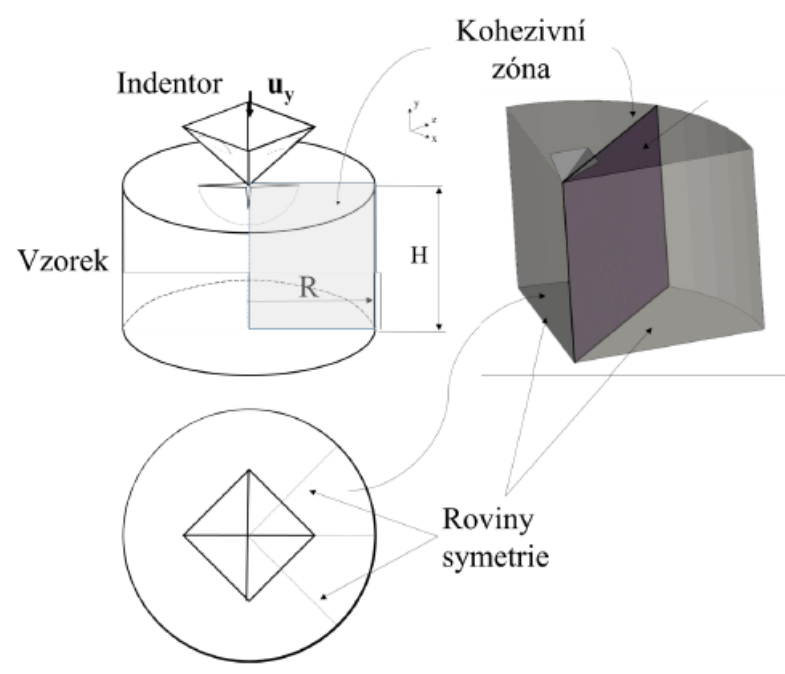

Obr. 2 Schéma 3D modelu

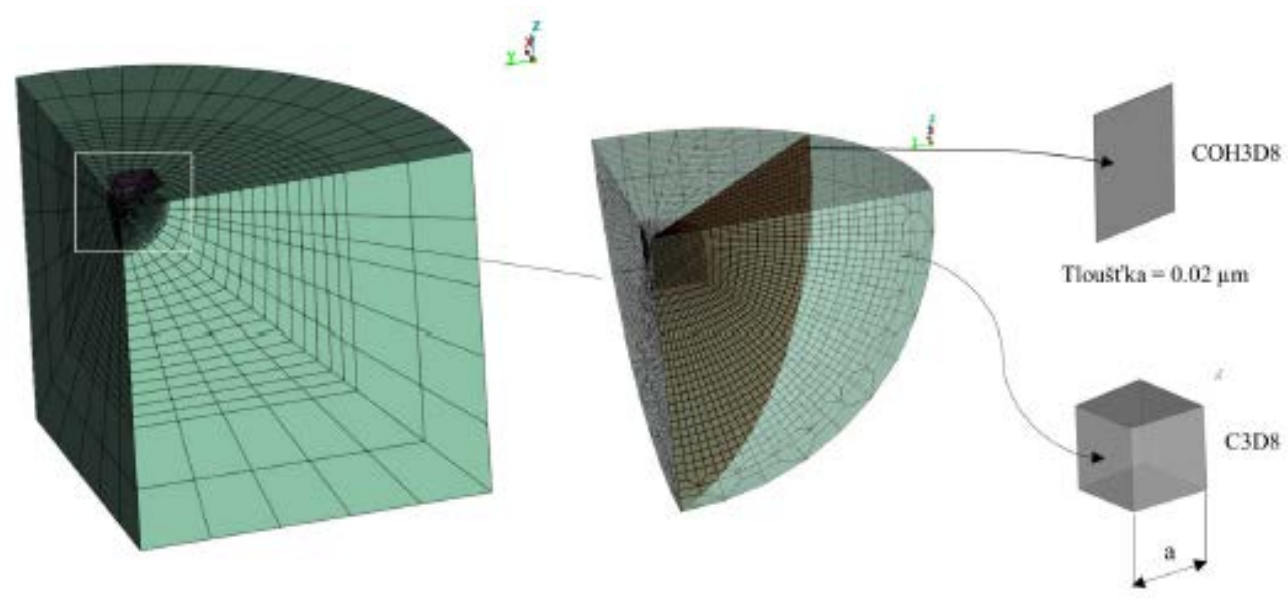

Obr. 3 Sít' 3D modelu); (Zíta, 2020)

\subsection{Porovnání výsledků měření s MKP výpočty}

Z indentačního měření skla byla zaznamenána a analyzována indentační křivka. Za použití metody Olivera a Pharra byl stanoven Youngův modul $E$ a tvrdost skla $H$, (Oliver a Pharr, 2011). Výsledky lomové houževnatosti $K_{I C}$ byly stanoveny podle známých vztahů od různých autorů, (Ćorić et al., 2017). Změřené a vypočítané hodnoty jsou porovnány v tabulce 1 . Výsledky simulace byly analyzovány stejným způsobem jako výsledky měření. Výjimkou je výpočet lomové houževnatosti, který byl proveden jednak podle známých vztahů (Ćorić et al., 2017) ale také na základě energií potřebných pro vytvoření příslušných ploch trhlin. Energie jsou jedním z výstupů numerické simulace. $V$ tabulce 1 je vidět porovnání výsledků měření a výpočtů. 
Tab. 1 Porovnání výsledků měření a výsledků MKP

\begin{tabular}{lll}
\hline Parametr & Měření & MKP výpočet \\
\hline Youngův modul E [MPa] & $73400 \pm 900$ & 73400 \\
Tvrdost H [MPa] & $6576 \pm 59$ & 6780 \\
Poloviční délka diagonály vtisku $[\mu m]$ & $64 \pm 2$ & 59 \\
Poloviční délka trhliny c $[\mu m]$ & $266 \pm 22$ & 270 \\
$\mathrm{~K}_{\mathrm{IC}}\left[\mathrm{MPa} \mathrm{m}^{1 / 2}\right]$ (Niihara) & $1 \pm 0.13$ & 0.97 \\
$\mathrm{~K}_{\mathrm{IC}}\left[\mathrm{MPa} \mathrm{m}^{1 / 2}\right]$ (Anstis) & $0.65 \pm 0.12$ & 0.59 \\
$\mathrm{~K}_{\mathrm{IC}}\left[\mathrm{MPa} \mathrm{m}{ }^{1 / 2}\right]$ (Myioshi) & $0.699 \pm 0.09$ & 0.66 \\
$\mathrm{~K}_{\mathrm{IC}}\left[\mathrm{MPa} \mathrm{m}^{1 / 2}\right]$ (Von Mises) & - & 0.49 \\
$\mathrm{~K}_{\mathrm{IC}}\left[\mathrm{MPa} \mathrm{M}^{1 / 2}\right]$ (Drucker Prager) & - & 0.63 \\
$\mathrm{~W}_{\mathrm{unrel}} / \mathrm{W}_{\mathrm{tot}}$ & $0.47 \pm 0.004$ & 0.43 \\
\hline
\end{tabular}

Na obrázku 5 je znázorněno porovnání měřeného vzorku (levá část obrázku) a magnituda deformace jako výsledek numerické simulace (pravá část obrázku). V obou př́padech se jedná o vizualizaci plně odlehčeného stavu. Je patrné, že výsledky simulace jsou velmi podobné výsledkům měření. Velmi dobrou shodu vykazují i indentační křivky viz obrázek 4.

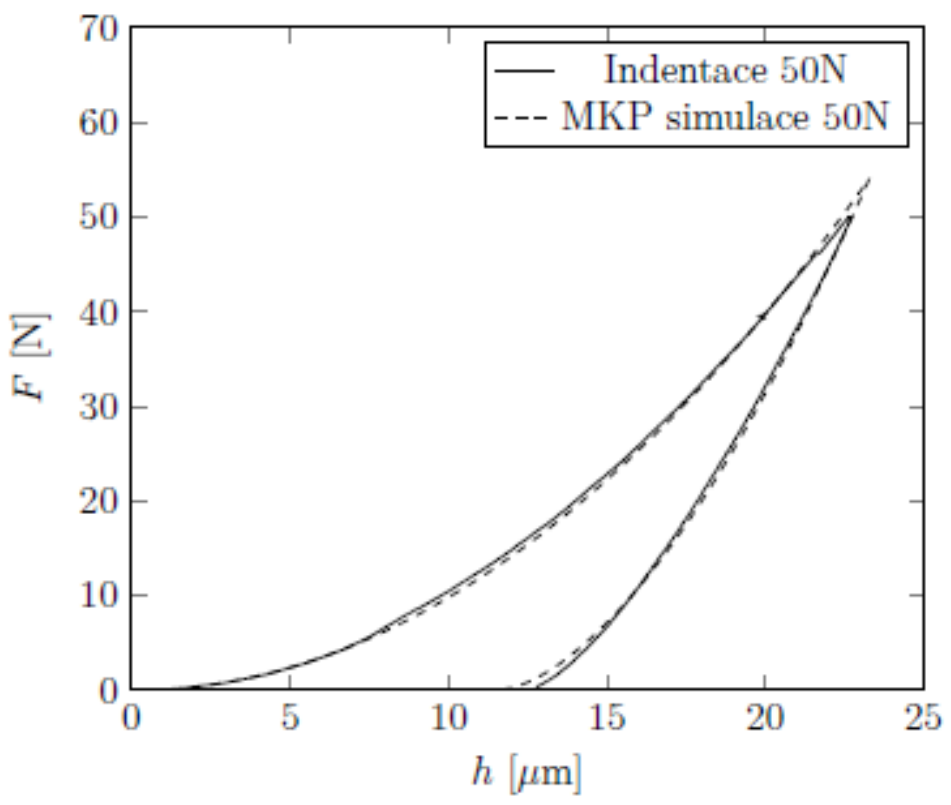

Obr. 4 Porovnání výsledků měření a MKP simulace (indentace do skla)); (Zíta, 2020) 


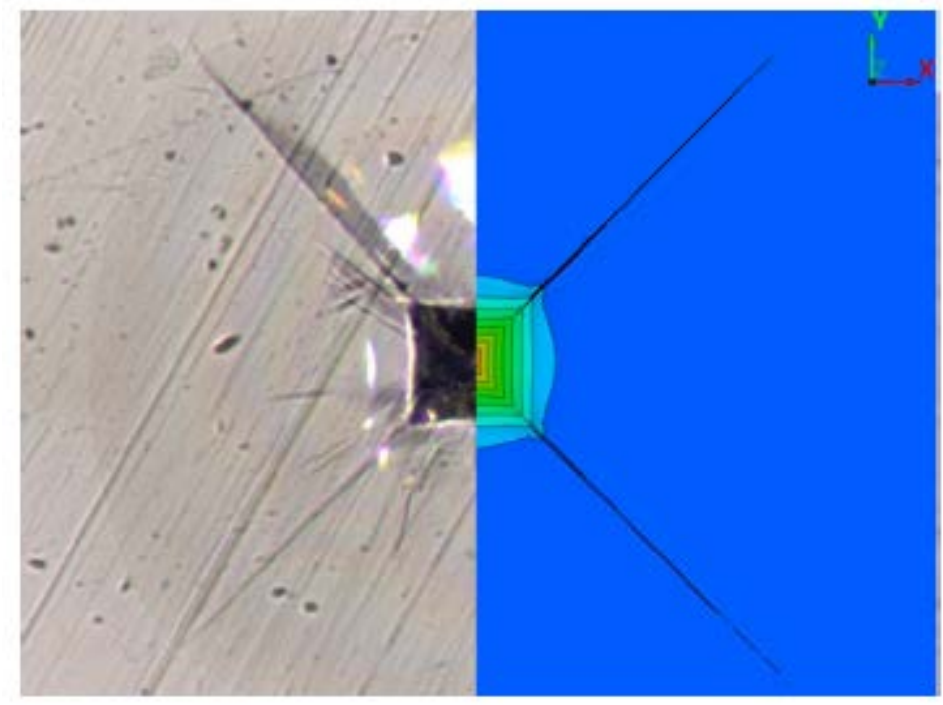

Obr. 5 Porovnání změřených a vypočítaných trhlin); (Zíta, 2020)

\section{ZÁVĚR}

Výsledky simulace indentace ukazují velmi dobrou shodu s měřením. Indentační křivky se shodují. Rozměry vzniklých trhlin jsou také téměř shodné. Je třeba poznamenat, že vypočítaná lomová houževnatost, která vychází z energií uvolněných při tvorbě trhlin, vykazuje nižších hodnot v porovnání s měřením. To je pravděpodobně způsobeno poddajností rámu měřicího přístroje. Pro zpřesnění modelu je třeba zahrnout poddajnost př́stroje do numerické simulace.

\section{Poděkování}

Rád bych poděkoval týmu Výzkumného centra v dopravě (VVCD) za umožnění reálných měření, které podpořily řadu kvalifikačních prací a odborných prací.

\section{Literatura}

CSN EN ISO 14577-1. 2002. Kovové materiály - Instrumentovaná vnikací zkouška stanovení tvrdosti a materiálových parametrů - Část 1. Zkušební metoda, 31s.

Ćorić, D., Rejnjo, M.M., a Ćurković, L. 2017. Vickers indentation fracture toughness of Y-TZP dental ceramics. International Journal of Refractory Metals and Hard Materials, 41(2), 14-19.

Lawn, B.R. a Evans A.G. 1977. A model for crack initiation in elastic/plastic indentation fields. Journal of Materials Science, 12, 2195-2199.

Lawn, B.R., Evans, A.G. a Marshall, D.B. 1980. Elastic/Plastic Indentation Damage in Ceramics: The Median/Radial Crack System. The American Ceramic Society, 63(9-10), 561-566.

Oliver, W.C. a Pharr, G.M., 2004. Measurement of hardness and elastic modulus by instrumented indentation: Advances in understanding and refinements to methodology.Journal of materials research, 19(1), 3-20.

Zíta, D. 2020. Modelování indentačních procesů. Disertační práce, 112 s. Univerzita Pardubice. 